\title{
Numerical Modelling of the Calcination Process in a Cement Kiln System
}

\author{
Amila Chandra Kahawalage Morten C. Melaaen Lars-André Tokheim \\ Department of Process, Energy and Environmental Technology, Faculty of Technology, Natural Sciences and Maritime \\ Sciences, University College of Southeast Norway, 3918, Porsgrunn, Norway \\ \{amila.c.kahawalage, Morten.C.Melaaen, Lars.A.Tokheim\} @usn.no
}

\begin{abstract}
The calcium carbonate decomposition into calcium oxide and carbon dioxide is a key process step in a cement kiln. The reaction requires thermal energy input, and pulverized coal is the fuel typically used for this purpose in the cement industry. Coal can in many cases be replaced by different types of alternative fuels, but this may impact process conditions, emissions or product quality. In this study, CFD simulations were carried out to investigate the possibility to replace $50 \%$ of the coal by refuse derived fuel (RDF). The spatial distribution of gas and particle temperatures and concentrations were calculated, and the simulations indicated that replacement of coal by RDF resulted in a reduction of fuel burnout, lower gas temperatures and a lower degree of calcination.
\end{abstract}

Keywords: precalciner, calcination, refuse derived fuel, computational fluid dynamics

\section{Introduction}

Cement is a key building material in construction industries and its demand is continually going up due to population growth and development. The energy required in cement production is supplied by electricity and thermal energy. In the manufacturing process, thermal energy is used mainly during the burning process.

The typical manufacturing process, which is schematically represented in Figure 1, starts with mining of limestone (high in calcium carbonate, $\mathrm{CaCO}_{3}$ ) and is followed by crushing, adding of additives such as clay, sand and iron to get the required chemical composition and grinding of this mixture. The intermediate product is called 'raw meal'. After homogenization, the raw meal becomes suitable for burning in the kiln system. The kiln feed is preheated, calcined, sintered and cooled in the kiln system, resulting in a dark grey nodular material called clinker. The clinker is mixed with some gypsum and other additives and ground to the final product cement.

A precalciner kiln system is the basis for this study. It normally consists of a preheater, a precalciner (also known as a calciner), a rotary kiln and a cooler. The kiln feed (i.e. the raw meal) is heated in the preheater and then sent to the precalciner where typically $85-95 \%$ of the calcination takes place. Calcination is the process of calcium carbonate decomposition into calcium oxide $(\mathrm{CaO})$ and carbon dioxide $\left(\mathrm{CO}_{2}\right)$, typically occurring at a temperature around $850-900^{\circ} \mathrm{C}$. As the calcination is an endothermic reaction $\left(\sim 1.7 \mathrm{MJ} / \mathrm{kgCaCO}_{3}\right)$, fuel is combusted in the calciner. In the rotary kiln, the remaining calcination is completed and clinker is formed.

Numerical modelling is a widely used tool for analysis and optimization of industrial process because it reduces time consumption and costs of doing fullscale tests. Computational fluid dynamics (CFD) modelling can be used to make numerical 3D simulations of different processes, for example the decarbonation and combustion in the cement kiln precalciner.

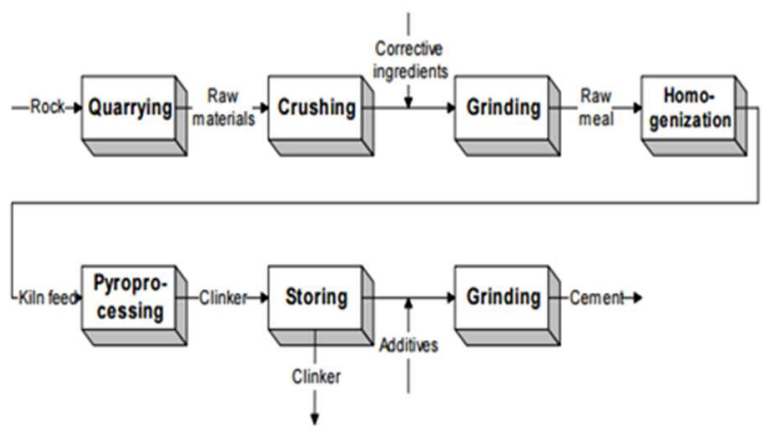

Figure 1. Principal drawing of the cement manufacturing process (Tokheim, 1999)

Results from modelling of cement kiln systems have been reported in some articles. When coal was cocombusted with meat and bone meal (MBM), the impact of fuel particle size and feeding positions in a rotary kiln was investigated (Ariyaratne et al., 2015) using a CFD simulation. This study revealed that although same thermal energy was supplied, when introducing MBM the kiln inlet temperature was reduced due to combined effect of moisture content, ash content and air demand. (Mikulčić et al., 2014) conducted a numerical study of co-firing pulverized coal and biomass inside a cement calciner and found that when coal was replaced with biomass, the fuel burnout and the $\mathrm{CaCO}_{3}$ decomposition 
was reduced. Another numerical modeling study reports a CFD simulation of a calciner with two different case studies of $100 \%$ coal and $100 \%$ pet coke (Fidaros et al., 2007). The use of CFD to predict the precalciner process behavior was proven by (Kurniawan, 2004).

Energy-wise and product efficiency-wise the precalciner plays CFD can be used to predict the precalciner process behavior was an important role in a cement kiln system as it completes around $85 \%$ of the calcination. CFD is a well-proven method to investigate flow, heat transfer and mass transfer phenomena in process equipment units. The aim of this study was to get detailed information about temperatures, calcination degree and fuel burnout in the precalciner system of a Norwegian cement plant with an annual clinker production capacity of about $1 \mathrm{Mt}$. The commercial software ANSYS Fluent was used to conduct the study.

\section{Theory}

The gas phase was modelled using the Euler approach, and to model the flow of the solid particles, the Lagrange method was used. For the gas phase, the equations for conservation of mass, momentum and energy (equations 1-4) are used.

$$
\begin{gathered}
\frac{\partial \rho}{\partial t}+\nabla \cdot(\rho \vec{v})=S_{m} \\
\frac{\partial(\rho \vec{v})}{\partial t}+\vec{v} \cdot \nabla(\rho \vec{v})=-\nabla p+\nabla \cdot(\overline{\bar{\tau}})+\rho \vec{g}+\vec{F} \\
\overline{\bar{\tau}}=\mu\left[\left(\nabla \vec{v}+\nabla \vec{v}^{T}\right)-\frac{2}{3} \nabla \cdot \vec{v} I\right] \\
\frac{\partial(\rho E)}{\partial t}+\nabla \cdot(\vec{v}(\rho E+p))=\nabla \cdot\left[k_{e f f} \nabla T-\sum_{j} h_{j} \vec{J}_{j}+\right. \\
(\overline{\bar{\tau}} \overline{\overline{e f f}} \cdot \vec{v})]+S_{h}
\end{gathered}
$$

Here, $S_{m}$ is the mass added to the continuous phase from particles due to fuel devolatilisation, char combustion and raw meal calcination, and $S_{h}$ is the added energy to the continuous phase due to chemical reactions. To model the turbulence, the two equation $k-\epsilon$ turbulence model was used. Particle trajectories were defined by equation 5 .

$$
\frac{d \vec{u}_{p}}{d t}=F_{D}\left(\vec{v}-\vec{u}_{p}\right)+\frac{\vec{g}\left(\rho_{p}-\rho\right)}{\rho_{p}}+\vec{F}
$$

Here, $F_{D}$ is the drag force on the particle, which for spherical particles can be calculated by equation 6 .

$$
F_{D}=\frac{18 \mu}{\rho_{p} d_{p}^{2}} \frac{C_{D} R e}{24}
$$

Figure 2 shows how a CFD modelling is sequenced for combustion of a solid fuel particle. First the fuel particle is heated whereby moisture evaporates. When the particle reaches the boiling point of water, all free moisture evaporates. After that the volatile part of the

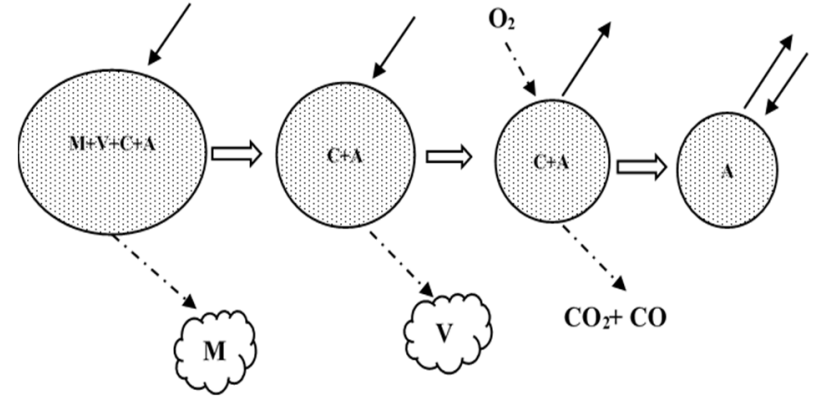

Figure 2. CFD Modelling steps of combustion of a solid fuel particle $(\mathrm{M}=$ moisture, $\mathrm{C}=$ char, $\mathrm{V}=$ volatile compounds, $A=$ ash)

fuel particle is devolatilized, and finally the char fraction, which is very rich in carbon, reacts with $\mathrm{O}_{2}$ and produces $\mathrm{CO}$ and $\mathrm{CO}_{2}$. (In the present study, it was assumed that only $\mathrm{CO}_{2}$ is produced in this reaction.) When the fuel particle is $100 \%$ burnt, i.e. when all the carbon has been oxidized, only ash is left.

A single rate devolatilisation model was used for both coal and refuse derived fuel (RDF). Char combustion was modelled with the kinetic/diffusion limited method. Devolatilisation was modeled by the single rate devolatilisation model given in equation 7 and 8 . The rate constants for coal and RDF were taken from (Badzioch and Hawksley, 1970) and (Wang et al., 2014), respectively.

$$
\begin{gathered}
-\frac{d m_{p}}{d t}=k\left[m_{p}-\left(1-f_{v, o}\right)\left(1-f_{w, o}\right) m_{p, o}\right] \\
k=A_{1} e^{-(E / R T)}
\end{gathered}
$$

Char combustion was modeled the by kinetic/diffusion surface rate model. The rate constant for coal was used as in (Baum and Street, 1971) and (Field, 1969). The rate constant for RDF was taken from (Wang et al., 2014).

$$
\begin{aligned}
& D_{o}=C_{1} \frac{\left[\left(T_{p}+T_{\infty}\right) / 2\right]^{0.75}}{d_{p}} \\
& R=C_{2} e^{-\left(E / R T_{p}\right)} \\
& \frac{d m_{p}}{d t}=-A_{p} p_{o x} \frac{D_{o} R}{D_{o}+R}
\end{aligned}
$$

Particle heat transfer during the initial heating and after the devolatization and char combustion is given by equation 13 .

$$
m_{p} c_{p} \frac{d T_{p}}{d t}=h A_{p}\left(T_{\infty}-T_{p}\right)+\epsilon_{p} A_{p} \sigma\left(\theta_{R}^{4}-T_{p}^{4}\right)
$$

The particle heat transfer during devolatization is given by equation 14 . 


$$
\begin{gathered}
m_{p} c_{p} \frac{d T_{p}}{d t}=h A_{p}\left(T_{\infty}-T_{p}\right)-\frac{d m_{p}}{d t} h_{f g}+ \\
\epsilon_{p} A_{p} \sigma\left(\theta_{R}^{4}-T_{p}^{4}\right)
\end{gathered}
$$

The particle heat balance during the char combustion is given by equation 15 .

$$
\begin{gathered}
m_{p} c_{p} \frac{d T_{p}}{d t}=h A_{p}\left(T_{\infty}-T_{p}\right)-f_{h} \frac{d m_{p}}{d t} H_{r e c}+ \\
\epsilon_{p} A_{p} \sigma\left(\theta_{R}^{4}-T_{p}^{4}\right)
\end{gathered}
$$

The $\mathrm{P}-1$ radiation model was used to implement the radiation heat transfer for the gas phase and the particle phase. The gas phase reaction was modelled using a finite-rate/eddy-dissipation model. In this study, it was considered that the volatile fraction of coal and RDF reacts with $\mathrm{O}_{2}$ and produces $\mathrm{CO}$ and $\mathrm{H}_{2} \mathrm{O}$. Then $\mathrm{CO}$ reacts with $\mathrm{O}_{2}$ and produce $\mathrm{CO}_{2}$. The required kinetic and eddy-dissipation model data were obtained from (Kurniawan, 2004).

Char was assumed to be $100 \%$ carbon $(\mathrm{C})$, which reacts with $\mathrm{O}_{2}$ and produces $\mathrm{CO}_{2}$. It was assumed that raw meal is pure $\mathrm{CaCO}_{3}$. The $\mathrm{CaCO}_{3}$ decomposition kinetics were according to (Borgwardt, 1985).

$$
\begin{gathered}
\mathrm{CaCO}_{3(s)} \stackrel{\Delta}{\rightarrow} \mathrm{CaO}_{(s)}+\mathrm{CO}_{2(g)} \\
\frac{d m_{\mathrm{CaCO}_{3}}}{d t}=-k_{s} A_{\mathrm{CaCO}_{3}} \\
k_{s}=\mathrm{Ae}^{-\left(E_{a} / R T\right)}
\end{gathered}
$$

\section{Simulation setup}

Figure 3 shows a 3-D model of the precalciner unit currently in operation at Norcem cement plant in Brevik. Figure 4 shows its front view.

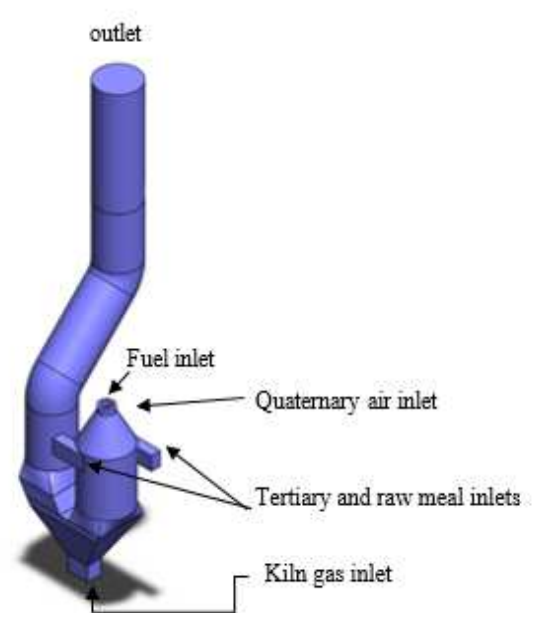

Figure 3. 3-D view of precalciner at Norcem cement plant
It has two tangential inlets to introduce raw meal and tertiary air. Quarternary air is introduced at the top of the calciner via a separate inlet, and there is also a separate inlet at the top for fuel (coal) supplied with conveying air. Moreover, there is a separate cooling air inlet.

The ANSYS Fluent CFD software was used to model the unit. The computational domain has 489,766 elements and is a combination of hexahedral, tetrahedral and prism elements.

Table 1. Approximate analysis of coal and RDF

\begin{tabular}{|l|c|c|}
\hline Content & $\begin{array}{c}\text { Coal } \\
\text { (Ariyaratne, } \\
2014)\end{array}$ & $\begin{array}{c}\text { RDF } \\
\text { (Tokheim, } \\
1999)\end{array}$ \\
\hline Moisture (\%) & 1 & 8.3 \\
\hline Volatiles (\%) & 23 & 71.1 \\
\hline Char $(\%)$ & 62.4 & 10.3 \\
\hline Ash $(\%)$ & 13.6 & 10.3 \\
\hline
\end{tabular}

Table 2. Ultimate analysis of coal and RDF

\begin{tabular}{|c|c|c|}
\hline $\begin{array}{c}\text { Element (dry } \\
\text { and ash-free } \\
\text { basis) }\end{array}$ & $\begin{array}{c}\text { Coal } \\
\text { Ariyaratne, } \\
2009)\end{array}$ & $\begin{array}{c}\text { RDF } \\
\text { (Tokheim, } \\
1999)\end{array}$ \\
\hline $\mathrm{C}(\%)$ & 85.3 & 54.3 \\
\hline $\mathrm{H}(\%)$ & 4.6 & 8.1 \\
\hline $\mathrm{O}(\%)$ & 6.5 & 35.8 \\
\hline $\mathrm{N}(\%)$ & 2.0 & 1.2 \\
\hline $\mathrm{S}(\%)$ & 1.6 & 0.6 \\
\hline
\end{tabular}

The approximate and ultimate analyses of coal and RDF are shown in Table 1 and Table 2, respectively, and these values were used as input values in Fluent. The Mean particle size values of 53, 2500 and $60 \mu \mathrm{m}$ were used for coal, RDF and raw meal respectively.

Two cases were defined. In Case 1, which can be taken as the reference case for comparison purposes, coal was used as the only fuel. In Case 2, a mixture of $50 \%$ coal and $50 \%$ RDF was used. In both cases the same fuel energy was supplied. The boundary conditions and process conditions for the test cases are given in the Table 3. A slightly higher tertiary air flow rate was used in Case 2 in order to operate with the same excess air value in both cases. 


\section{Results and discussion}

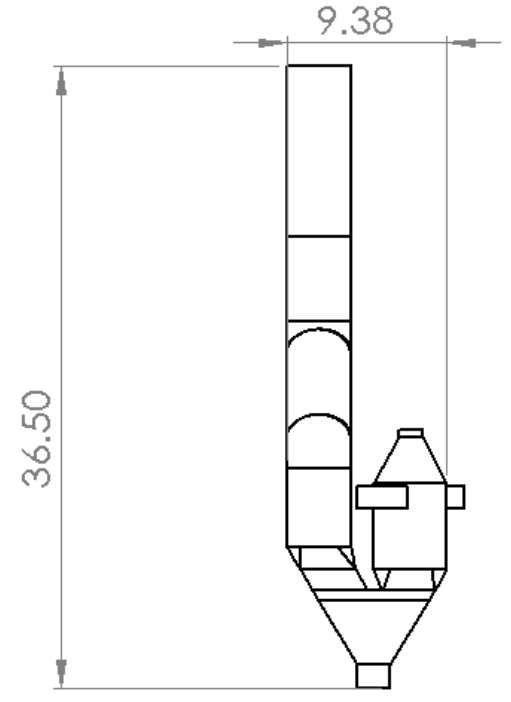

Figure 4. Front view of the precalciner (dimensions are in meters)

Table 3. Definition of cases

\begin{tabular}{|l|c|c|}
\hline Parameter & Case 1 & Case 2 \\
\hline Fuel Energy (MW) & 79.5 & 79.5 \\
\hline Tertiary air $(\mathrm{t} / \mathrm{h})$ & 94.5 & 93.0 \\
\hline Quarternary air $(\mathrm{t} / \mathrm{h})$ & 17.1 & 17.1 \\
\hline Raw meal mass flow rate $(\mathrm{t} / \mathrm{h})$ & 184.3 & 184.3 \\
\hline Coal mass flow rate $(\mathrm{t} / \mathrm{h})$ & 10.1 & 5.1 \\
\hline RDF mass flow rate $(\mathrm{t} / \mathrm{h})$ & - & 7.8 \\
\hline
\end{tabular}

The composition of tertiary and quarternary air were taken as $21 \% \mathrm{O}_{2}$ and $79 \% \mathrm{~N}_{2}$. The kiln gas composition was taken as $74.4 \% \mathrm{~N}_{2}, 7.6 \% \mathrm{O}_{2}, 5.0 \% \mathrm{H}_{2} \mathrm{O}$ and $13.0 \% \mathrm{CO}_{2}$. The tertiary air, quarternary air and raw meal inlet temperatures were all set to $800^{\circ} \mathrm{C}$, which are quite typical values for the given kiln system. The kiln gas inlet temperature was taken as $1050{ }^{\circ} \mathrm{C}$.

As the convergence criteria, all variables were kept below the residual value of $10^{-4}$. The SIMPLE algorithm was used to to solve the Navier-Stokes equations. The PRESTO! scheme was used for pressure discretization, and first order discretization schemes were used for momentum, turbulent dissipation and turbulent kinetic energy. All other parameters were discretized with second order schemes.

During the simulation, the progress of the gas phase temperature and species mole fractions were monitored at the outlet. When they approached steady state, the simulation was considered as converged.

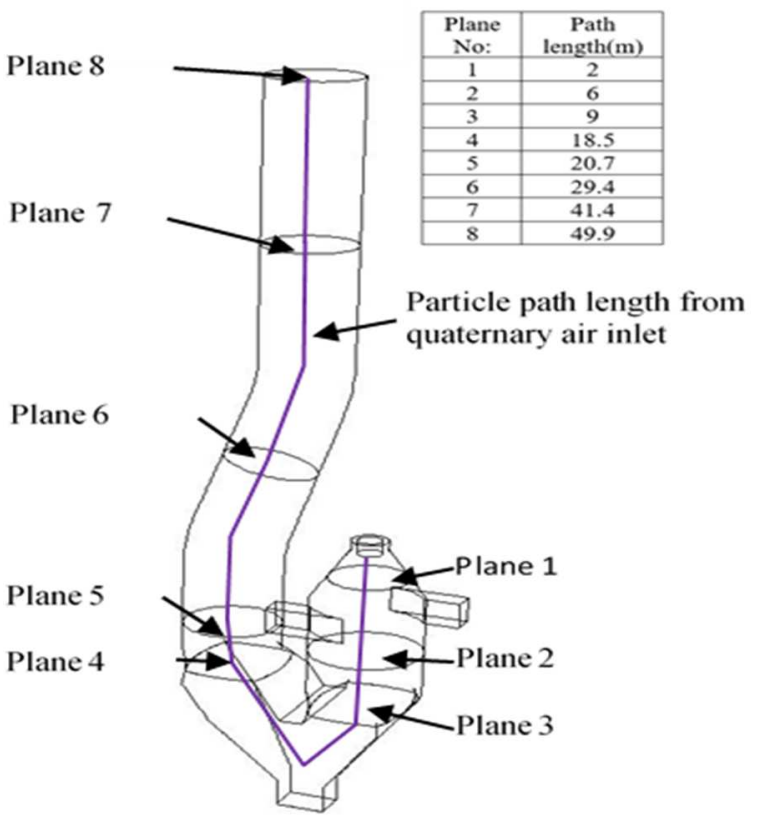

Figure 5. Particle path along the precalciner

Eight planes were created along the precalciner, as shown in Figure 5, to extract data of the gas phase and the particle phase. Gas phase data were calculated as area-weighted averages for each plane.

Figure 6 (a) and (b) shows the variation of temperature and gas phase composition along the precalciner path length. The connection between path length and plane position is seen in Figure 5. In both cases, the oxygen mole fraction is reduced along the path length due to combustion. Carbon dioxide and water are generated proportionally due to combustion. In both cases, the $\mathrm{CO}_{2}$ generated by the calcination reaction also increases, and the temperature resulting from fuel combustion is used to heat and calcine the raw meal. This can also be seen in Figure 7. At the end of the path length, the gas, fuel and meal temperatures are quite close, ranging from about 860 to $900{ }^{\circ} \mathrm{C}$, which is typically what is experienced in the real process.

There is an increase in gas temperature over the the initial path length (the first $20 \mathrm{~m}$ ). However, as the calcination process escalates, the temperature is gradually reduced due to heat transfer from the gas to the meal. 


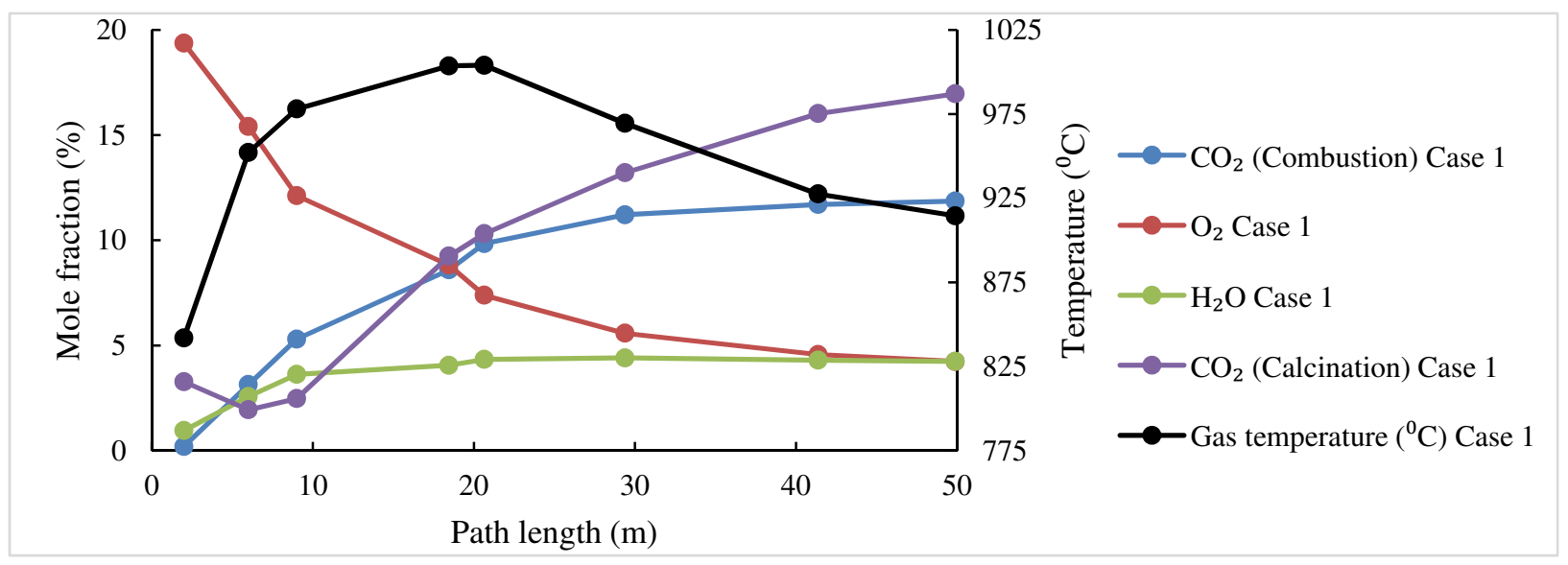

(a)

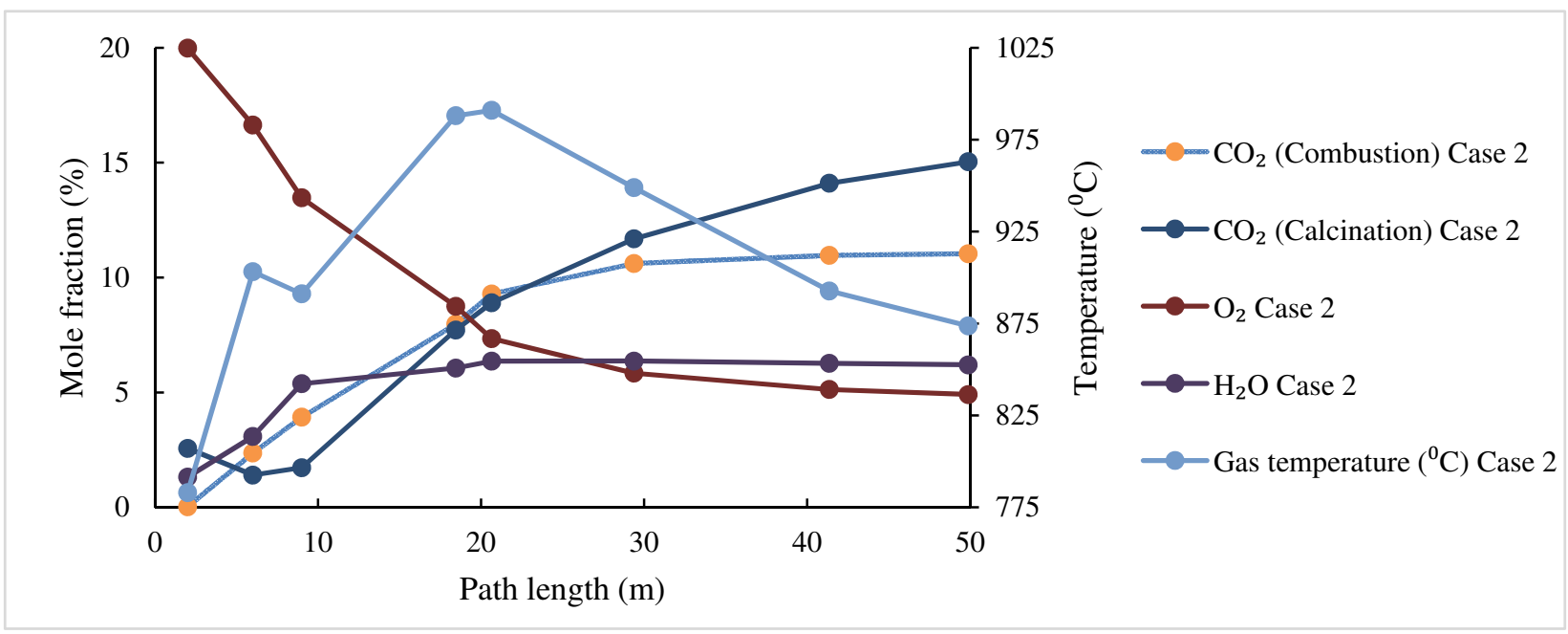

(b)

Figure 6. Variation of gas temperature and mole fraction of $\mathrm{CO}_{2}$ (from calcination + combustion) $\mathrm{O}_{2}$ and $\mathrm{H}_{2} \mathrm{O}$ (a) for Case 1 (b) for Case 2

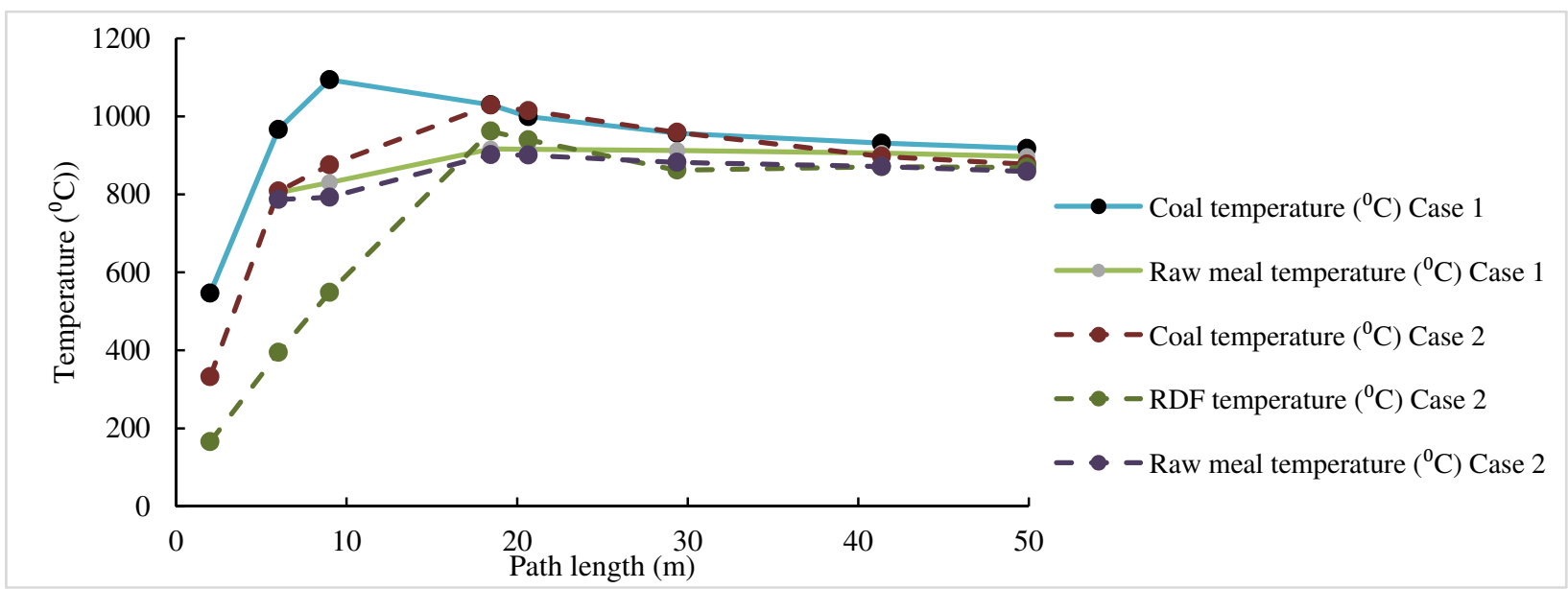

Figure 7. Temperature distribution of coal, raw meal and RDF for Case 1 and Case 2 


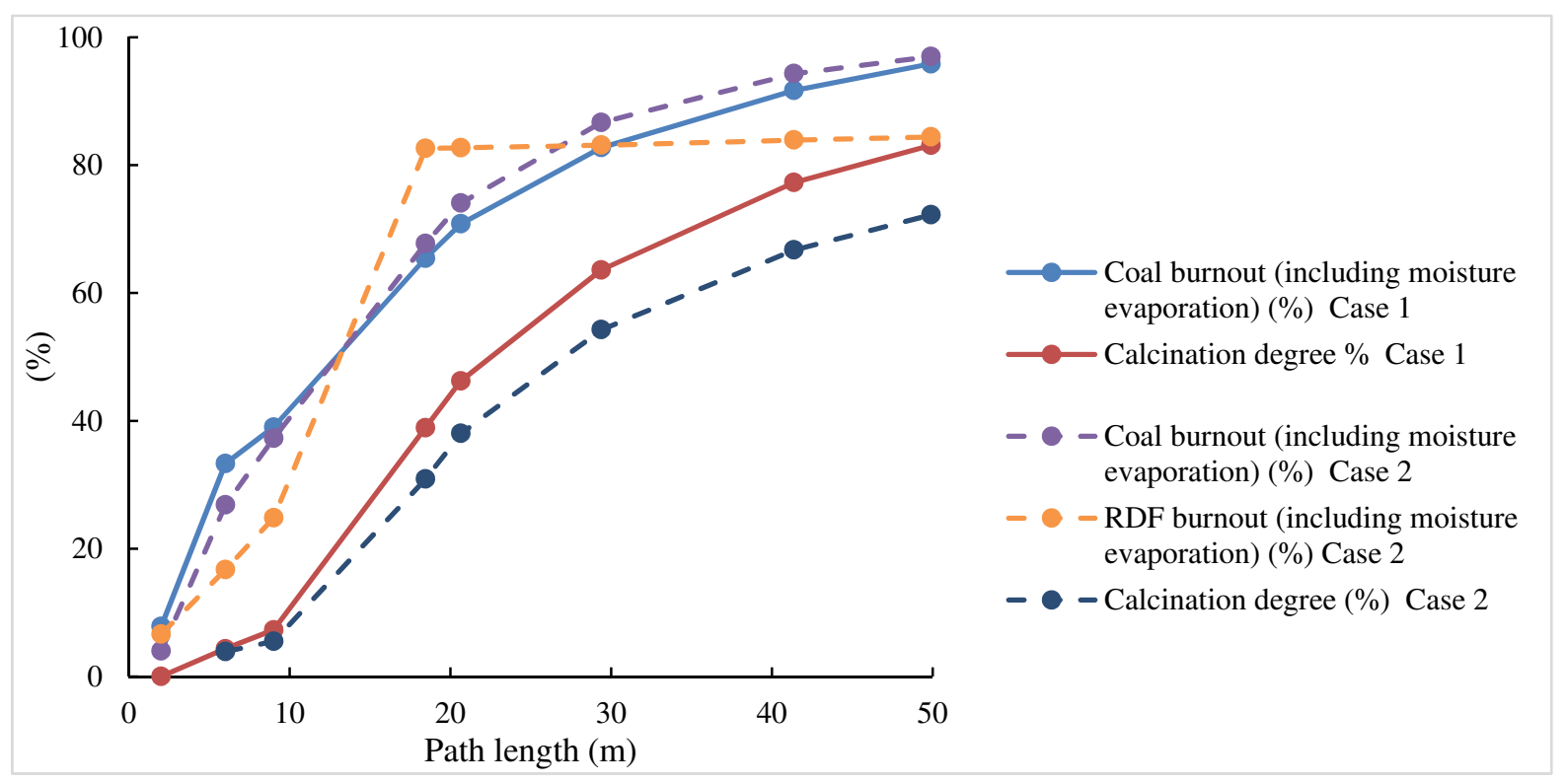

Figure 8. Calcination degree and fuel burnout for Case 1 and Case 2

Figure 8 shows the calcination degree and fuel burnout for both cases. Although the same energy was supplied in Case 1 and Case 2, the calcination degree is lower in the latter case. There are two reasons for this. The main reason is the high moisture content of RDF (see Figure 6 ), which reduces the particle temperature and gives a lower burnout of this fuel (see Figure 8).

Hence, less energy is released to support the decarbonation. This happens because in the initial stage, energy is spent on evaporating the moisture. A consequence of this is that RDF char burning takes place later, i.e. more downstream along the path length. In addition, since the RDF particles are bigger, it takes more time to reach complete combustion.

\section{Conclusion}

In this study CFD tool has been applied to get detailed information about temperatures, calcination degree and fuel burnout in a precalciner system. Even if the fuel energy supply is not changed, replacing part of the coal with $\mathrm{RDF}$ reduces the calcination degree in the process, which can be seen as quality reduction in precalcined meal. The reason for the reduced calcination degree is the poorer burnout of the RDF particles caused by higher moisture content and larger particles. The method applied in this study can be used to evaluate the calcination process under different process conditions and to optimize the process when coal is replaced by other alternative fuels with different characteristics.

\section{Acknowledgement}

Financial support from Telemark Fylkeskommune is greatly acknowledged, as is the support from the Norwegian Research Council through the project "Optimised and increased use of Refuse Derived Fuel as substitute for coal at Norcem Brevik cement plant" (BIA project 245690).

\section{Nomenclature}

\begin{tabular}{cl}
$\rho$ & Gas density $\left(\mathrm{kgm}^{-3}\right)$ \\
$\vec{v}$ & Gas velocity vector $\left(\mathrm{ms}^{-1}\right)$ \\
$S_{m}$ & Mass source $\left(\mathrm{kgm}^{-3} \mathrm{~s}^{-1}\right)$ \\
$p$ & Static pressure $\left(\mathrm{Nm}^{-2}\right)$ \\
$\overline{\bar{\tau}}$ & Stress tenser $\left(\mathrm{Nm}^{-2}\right)$ \\
$\vec{g}$ & Acceleration of gravity $\left(\mathrm{ms}^{-2}\right)$ \\
$\vec{F}$ & External body force $(\mathrm{N})$ \\
$\mu$ & Molecular viscosity $\left(\mathrm{kgm}^{-1} \mathrm{~s}^{-1}\right)$ \\
$I$ & Unit tensor \\
$E$ & Total energy $\left(\mathrm{m}^{2} \mathrm{~s}^{-2}\right)$ \\
$k_{e f f}$ & Effective conductivity $\left(\mathrm{Wm}^{-1} \mathrm{~K}^{-1}\right)$ \\
$T$ & Gas temperature $(\mathrm{K})$ \\
$h_{j}$ & The enthalpy formation of $\mathrm{species}^{\mathrm{j}}$ \\
$\vec{J}_{j}$ & (Jkg $\left.\mathrm{J}^{-1}\right)$ \\
\hline$\overline{\bar{\tau}_{e f f}}$ & Diffusion flux of species $\mathrm{j}\left(\mathrm{kgm}^{-2} \mathrm{~s}^{-1}\right)$ \\
$S_{h}$ & Viscous dissipation term \\
$\vec{u}_{p}$ & Source of energy $\left(\mathrm{kgm}^{-1} \mathrm{~s}^{-3}\right)$ \\
$F_{D}$ & Particle velocity vector $\left(\mathrm{ms}^{-1}\right)$ \\
$\rho_{p}$ & Drag force on particle $\left(\mathrm{s}^{-1}\right)$ \\
$d_{p}$ & Particle density $\left(\mathrm{kgm}{ }^{-3}\right)$ \\
$C_{D}$ & Particle diameter $(\mathrm{m})$ \\
$R e$ & Drag coefficient \\
$m_{p}$ & Particle Reynold number \\
$k$ & Particle mass $(\mathrm{kg})$ \\
$f_{v, o}$ & Devolatilisation reaction rates constant \\
$f_{w, o}$ & Initial volatile fraction in fuel particle $(\%)$ \\
$m_{p, o}$ & Initial moisture fraction in particle $(\%)$ \\
& Particle initial weight $\left(\mathrm{kg}^{2}\right)$ \\
&
\end{tabular}




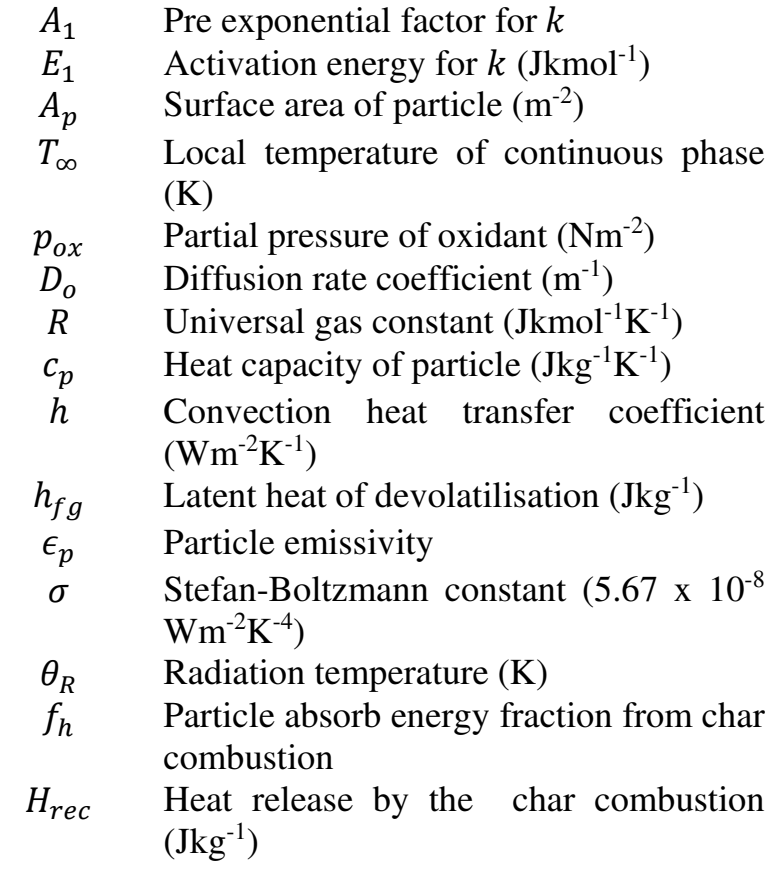

\section{References}

Ariyaratne, W. K. H. Alternative fuels in cement kilns characterization and experiments Master thesis, Telemark University College, Norway. 2009.

Ariyaratne, W. K. H. Utilization of Waste-derived Biofuels and Partly CO2-neutral Fuels in Cement Kilns. PhD thesis, Telemark University College. 2014.

Ariyaratne, W. K. H., Malagalage, A., Melaaen, M. C. \& Tokheim, L.-A. CFD modelling of meat and bone meal combustion in a cement rotary kiln - Investigation of fuel particle size and fuel feeding position impacts. Chemical Engineering Science, 123, 596608.2015.http://dx.doi.org/10.1016/j.ces.2014.10.048

Badzioch, S. \& Hawksley, P. G. W. Kinetics of Thermal Decomposition of Pulverized Coal Particles. Industrial \& Engineering Chemistry Process Design and Development, 9, 521-530.1970.10.1021/i260036a005

Baum, M. M. \& Street, P. J. Predicting the Combustion Behaviour of Coal Particles. Combustion Science and Technology, 3, 231-243.1971.10.1080/00102207108952290

Borgwardt, R. H. Calcination kinetics and surface area of dispersed limestone particles. AIChE Journal, 31, 103111.1985.10.1002/aic.690310112

Fidaros, D. K., Baxevanou, C. A., Dritselis, C. D. \& Vlachos, N. S. Numerical modelling of flow and transport processes in a calciner for cement production. Powder Technology, $\quad 171, \quad 81$ 95.2007.http://dx.doi.org/10.1016/j.powtec.2006.09.01 1

Field, M. A. Rate of combustion of size-graded fractions of char from a low-rank coal between $1200^{\circ} \mathrm{K}$ and $2000^{\circ} \mathrm{K}$. Combustion and Flame, 13, 237252.1969.http://dx.doi.org/10.1016/00102180(69)90002-9

Kurniawan, K. P. Studies of Fundamental Process Occurring in Pre-calciners and Cyclone Pre-heater Tower Using CFD. PhD thesis, University of Wales. 2004.
Mikulčić, H., Berg, E. V., Vujanović, M. \& Duić, N. Numerical study of co-firing pulverized coal and biomass inside a cement calciner. Waste Management \& Research, 32, 661-669.2014.doi:10.1177/0734242X14538309

Tokheim, L. A. The impact of staged combustion on the operation of a precalciner cement kiln. $\mathrm{PhD}$ thesis, Telemark College, Norway. 1999.

Wang, G., Silva, R. B., Azevedo, J. L. T., Martins-Dias, S. \& Costa, M. Evaluation of the combustion behaviour and ash characteristics of biomass waste derived fuels, pine and coal in a drop tube furnace. Fuel, 117, 809824.2014.http://dx.doi.org/10.1016/j.fuel.2013.09.080 